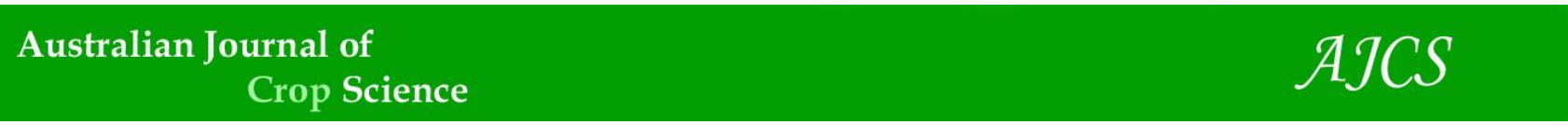

AJCS 15(05):725-742 (2021)

ISSN:1835-2707

doi: 10.21475/ajcs.21.15.05.p3129

\title{
Pollen morphology of Malvaceae genera from Saudi Arabia and its taxonomic significance
}

\author{
Kadry Abdel khalik ${ }^{1,2},{ }^{*}$, Suad Al-Ruzayza ${ }^{1}$, Abdullah Assiri ${ }^{4}$, Ahmed Elkordy $^{2,3}$ \\ ${ }^{1}$ Biology Department, Faculty of Applied Science, Umm-Al-Qura University, Makkah, Saudi Arabia \\ ${ }^{2}$ Botany and Microbiology Department, Faculty of Science, Sohag University, Sohag, Egypt \\ ${ }^{3}$ Botany and Microbiology Department, College of Science, Taibah University, Ola, Saudi Arabia \\ ${ }^{4}$ Forensic Lab-Criminal Evidence-Ministry of interior, Jeddah, Saudi Arabia
}

\section{*Corresponding author: Kadry3000@yahoo.com}

\begin{abstract}
Pollen morphology of 20 species belong to seven genera (Abutilon, Althaea, Hibiscus, Malva, Pavonia, Senra and Sida) of Malvaceae from Saudi Arabia were studied by using light microscope (LM) and scanning electron microscope (SEM). Quantitative and qualitative pollen morphological characters which vary among investigated taxa are found in the pollen polarity, symmetry, size, shape, polar axis, equatorial diameter, $P / E$ ratio, average height and width of spine, aperature character and spine index. The pollen grains vary from spheroidal, prolate spheroidal, oblate spheroidal to suboblate. All taxa were characterized by relatively large to medium sized pollen grains, numerous pores scattered irregularly all over the grain, and echinate sculpturing. Sida ovata is the largest size pollen grain (138.95) $\mu \mathrm{m}$. On the other hand, Malva parviflora showed the smallest pollen size (52.28 $\mu \mathrm{m})$. The average height and width of spine varied greatly among studied taxa. The highest spines $(20.65 \mu \mathrm{m})$ found in Sida ovata, while the shortest $(3.19 \mu \mathrm{m})$ was found in Abutilon pannosum. Results of the pollen shape, size, and exine sculpture characters offered useful data for evaluating the taxonomy of Malvaceae both on subgeneric and sectional levels. A key for the identification of the investigated taxa based on pollen grains characters is also provided.
\end{abstract}

Keywords: Malvaceae, Pollen, Saudi Arabia, Taxonomic, Morphology.

\section{Introduction}

Malvaceae are a worldwide family of herbs, shrubs and small trees with a primary concentration of genera in the tropical regions and comprises of some 244 genera including 4225 known species (Christenhusz and Byng, 2016). The family has been divided into five or six tribes: Malopeae, Malveae, Hibiscieae, Abutilieae, Ureneae and Decaschistieae (Duke and Doebley, 1995) (Krebs, 1994a,b).

The largest genera in terms of number of species are Hibiscus (580, including Pavonia), Sida (200), Abutilon (100), Dombeya (225), Triumfetta (150), Grewia (290) (Stevens, 2001).

The pollen morphology of this family or representatives of it, has attracted many scientists. The most important studies are (Erdtman, 1952; Nair, 1958; Saad, 1960; Nair, 1961; Prasad, 1963; Chaudhuri, 1965; Erdtman, 1969; Martin and Drew, 1969; Barth, 1975; Krapovickas, 1975; Tressens, 1974; Van Campo, 1976; Coetzee and Van Der Schijff, 1979;Hanks and Fryxell, 1979; Fernandez and Candau, 1981; Srivastava, 1982; El Naggar, 2004). Among these, only the most recent have been using SEM, with most having been based only on light microscopical studies.

Owing to the high economic value of some genera of the Malvaceae, several studies have been carried out on different perspectives of this family (El-Hadidi et al., 1999; and El Naggar $(2001 ; 2004)$

Saad (1960) considered that the pollen morphology in the family Malvaceae is quite distinctive which could apparently distinguish between the genera.

Furthermore, Christensen (1986) conducted a most comprehensive study on pollen of Malvaceae using both light (LM) and scanning electron microscopy (SEM). Moreover, he compared his results with the recent classification of the family (Hutchinson, 1967) with special reference to phylogeny, cytology and the evolutionary trends in pollen morphology. He pointed out that Malvaceae seems to be an ancient family with the tribes of Malveae and Abutileae having a long and distinct evolutionary history, while Hibisceae and Ureneae are closely allied tribes and can be regarded as the most advanced within the family. However, he admitted that the generic delimitation, is rather difficult among the studied species of the family based on pollen morphology.

Culhane and Blackmore (1988) divided the family into six pollen types, based on number of apertures, grains diameter and spinular morphology. However, Hosni and Araffa (1999) used pollen characteristics in combination with other 
morphological characteristics to differentiate between certain taxa from Egypt.

In the flora of Saudi Arabia, Chaudhary (1999) reported 17 genera and 31 species of Malvaceae.

The main object of the present study is to investigate and describe the pollen of some wild taxa of the family Malvaceae growing in Saudi Arabia, and to discuss the results obtained with recent classifications of the family.

\section{Results}

\section{Polarity and symmetry}

All investigated taxa generally have radially symmetrical apolar or isopolar pollen grains. However, all investigated taxa belong to Genus Abutilon characterized by isopolar pollen grains, while the pollen grains were polar in the rest of the studied taxa (Table 2).

\section{Pollen shape}

The ratio between the mean polar axis $(P)$ and the mean equatorial diameter $(E)$ can be used to assign the pollen grains to shape classes as follows (Punt et al., 1994).

$P / E=0.75-0.875$ Suboblate

$\mathrm{P} / \mathrm{E}=0.875-1.0$ Oblate spheroidal

$\mathrm{P} / \mathrm{E}=1.0$ Spheroidal

$P / E=1.1-1.4$ Prolate spheroidal

$P / E=1.14-1.33$ Subprolate

$P / E=1.33-2.0$ Prolate

Fig. 1 shows the mean polar axis plotted against mean equatorial diameter for each species measured. The peroblate and oblate grains was laid above this line and suboblate and oblate spheroidal near this line. The spheroidal grains perfectly resided along the $45^{\circ}$ line in Fig. 1 , with prolate and perprolate grains below this line and prolate spheroidal and subprolate near the line. In the investigated species, there is no broad variation in pollen shape.

Pollen grains are generally Prolate spheroidal, Spheroidal, Oblate spheroidal or Suboblate. However, it is spheroidal In Senra incana (Fig. 6, 18); Oblate spheroidal in Malva neglecta (Fig. 5, 13), Malva verticillata (Fig. 5, 15), Pavonia arabica (Fig. 5, 16), Sida alba (Fig. 6, 19) and S. ovata (Fig. 6, 20); Suboblate in Malva parviflora (Fig. 5, 14); Prolate spheroidal in the rest of studied taxa. In polar view the pollen grains are mostly circular in all studied taxa.

\section{Pollen Size}

Pollen grains of the Malvaceae are considered to be the largest among Angiosperms (Christensen, 1986). Pollen size varied greatly among the studied taxa. It ranged from 52.28 $\mu \mathrm{m}$ to $138.95 \mu \mathrm{m}$. Pollen grain size was found useful to distinguish between studied species especially at generic level. However, the largest pollen grain exceeds $100 \mu \mathrm{m}$ found in Althaea ludwigii, Hibiscus micranthus and Sida ovata (Table 2; Fig. 4, 9, 11 and Fig. 6, 20), respectively, while the smallest pollen grain ranges from $52.28 \mu \mathrm{m}$ to $56.06 \mu \mathrm{m}$ found in Malva parviflora and Malva neglecta (Table 2; Fig. 5, 14, 13), respectively. In the rest of the studied taxa, pollen grain ranges from $82.2 \mu \mathrm{m}$ to $96.3 \mu \mathrm{m}$ in the taxa of genus Pavonia, Hibiscus deflersii and Malva verticillata (Table 2; Fig. 5, 16; Fig. 6, 17; Fig. 4, 10; Fig. 5, 15), respectively. Taxa of genera Abutilon, Senra and Hibiscus purpureus characterized by relatively medium pollen grain size ranging from $60.96 \mu \mathrm{m}$ in Abutilon pannosum to 79.38 $\mu \mathrm{m}$ in Abutilon figarianum (Table 2; Fig. $3,5,6$ ), respectively, while it is $69.52 \mu \mathrm{m}$ and 72.86 in Senra incana and Hibiscus purpureus, respectively (Table 2; Fig. 6, 18 and Fig. 4, 12) respectively.

\section{Surface ornamentation}

All taxa under investigation were characterized by echinate exine (Table 2, Figs. 2-11). According to El Naggar (2004), one of the most prominent and interesting features of Malvaceous pollen is the echinations or prolongations of the exine into definite spines. Malvaceae is fairly advanced because of the echinate sculpturing and pantoporate character of its pollen grains (Perveen, 1993).

\section{Spines (echinae)}

Spines varied greatly in length and width among the investigated taxa. The average height of spines ranged from (3.19) $\mu \mathrm{m}$ in Abutilon pannosum to (20.65) $\mu \mathrm{m}$ in Sida ovata, while the average width ranging from (1.08) $\mu \mathrm{m}$ for Abutilon pannosum to $4.98 \mu \mathrm{m}$ for Hibiscus micranthus (Table 2 and Fig. 12). The number, height, and position of spines vary in the different plant families in which they occur and constitute some of the most significant characters for identification purposes (Pope, 1925). The variations in size, shape and surface distribution of spines in the pollen grains of Malvaceae are of significant value at different taxonomic levels as these are not only recorded at intergeneric level but also between species of the same genus.

\section{Spine index}

The proportion between the height and width of the spine at its base defines the spine configuration and is used as a taxonomic characteristic to delimit Malvaceous taxa. The present study shows that the highest value of spine index (5.17) is recorded for Pavonia arabica, while, the smallest (2.09) for Malva parviflora (Table 2; Fig. 13). The longest spines were observed in Sida ovata $(20.65 \mu \mathrm{m})$, while the shortest in Abutilon pannosum $(3.19 \mu \mathrm{m})$ (Table 2 and Fig.12).

\section{Apertures}

All investigated species are characterized by poly panto and zono porate aperturate. However, all taxa of the genus Abutilon were characterized by trizonoporate pollen grains (Table 2; Figs. 2, 3, 7, 8) while the rest of taxa under investigation characterized by Polypantoporate pollen grains (Table 2; Figs. 4, 5, 6, 9, 10, 11).

\section{Key to the studied taxa based on pollen grains characters}

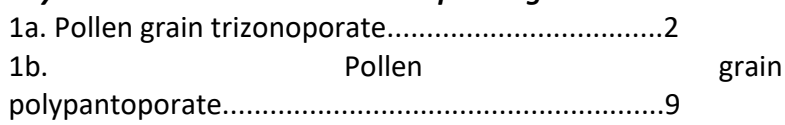

2a. Pollen grains with mean polar axis $(P)$ ranges from 60.96 to $68.37 \mu \mathrm{m}$..............................................................

2b. Pollen grains with mean polar axis $(P)$ ranges from 75.02

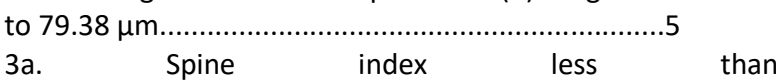
$\begin{array}{lll}3 a . & \text { Spine } \quad \text { index } & \text { less than } \\ 3.00 \ldots \ldots \ldots \ldots \ldots \ldots \ldots \ldots \ldots \ldots \ldots \ldots \ldots \ldots \ldots \ldots . . . & \text { Abutilon pannosum }\end{array}$

3b. Spine $\quad$ index exceed

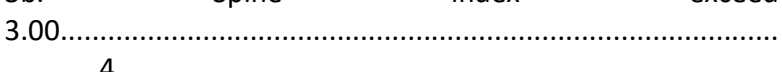

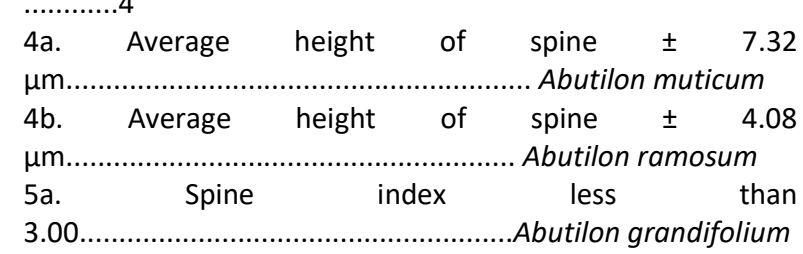


5b. Spine index exceed

3.00 6

6a. Average height of spine $<6$

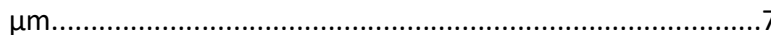

6b. Average height of spine $>6$

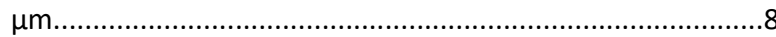

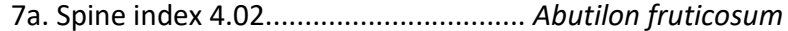

7b. Spine index $4.74 \ldots \ldots \ldots \ldots \ldots . . . . . . . . . . . . . .$. Abutilon bidentatum

8a. Spine index

3.56...................................................Abutilon hirtum

8 b. Spine index

4.51.....................................................Abutilon figarianum

9a. Pollen grains with mean polar axis (P) exceeds 100

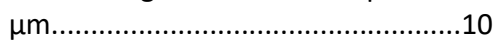

9b. Pollen grains with mean polar axis $(P)$ less than 100 $\mu \mathrm{m} . . . .$. .12

10a. Pollen grains Oblate spheroidal, with mean polar axis (P) up to $139 \mu \mathrm{m}$.......... Sida ovate

10b. Pollen grains Prolate spheroidal, with mean polar axis

(P) up to $129 \mu \mathrm{m} . . . \ldots \ldots \ldots \ldots \ldots \ldots . . . .11$

11a. Average height of spine \pm 16.85

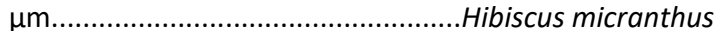

11b. Average height of spine \pm 6.00

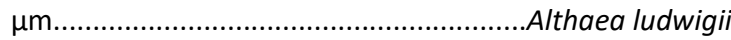

12a. Pollen grains Spheroidal, with very short spines 3.26

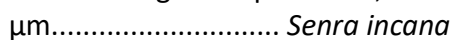

12b. Pollen grains Prolate spheroidal, Oblate spheroidal and Suboblate. . .13

13a. Pollen grains Suboblate, with mean polar axis $(P) 52.28$

$\mu \mathrm{m}$. ..... Malva parviflora.

13b. Pollen grains Prolate spheroidal, Oblate

spheroidal. . .14

14a. Pollen grains prolate

spheroidal 15

14b Pollen grains Oblate

spheroidal.

15a. Pollen grains with mean polar axis $(P)$ up to $75.00 \mu \mathrm{m}$, with relatively short spines $( \pm 4.43$

$\mu \mathrm{m})$. Hibiscus purpureus.

15b. Pollen grains with mean polar axis $(P)>75.00 \mu \mathrm{m}$, up to $97.00 \mu \mathrm{m}$, with relatively long spines $(12.50-16.00$

$\mu \mathrm{m})$. .16

16a. Spine index

3.00 . ..Hibiscus deflersii

16b. Spine index $>3.00$ .Pavonia burchellii

17a. Pollen grains with mean polar axis $(P)$ up to 56.06

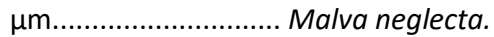

17b. Pollen grains with mean polar axis $(P)>56.06 \mu \mathrm{m}$, up to 95.00 ...18

18a. Average height of spine $\pm \quad 6.78$

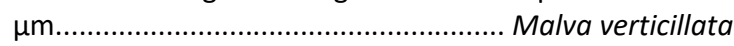

18b. Average height of spine $>6.78 \mu \mathrm{m}$, up to 17.00

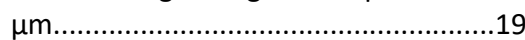

19a. Spine index

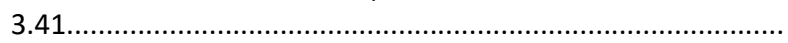

...... Sida alba

$19 b$.

Spine

index

5.17.......................

Pavonia arabica

\section{Discussion}

Palynologically Malvaceae is a stenopalynous family and pollen characters of this family are almost uniform (Tahavi, 2000). Saad (1960) studied the pollen morphology of 35 species of Malvaceae. He emphasized the importance of the aperture and spine characteristics, as well as exine stratification to distinguish between different taxa.

The results provide valuable characters for pollen morphological differences, which can be used as key characters for the distinction of certain taxa.

The pollen grains of genus Abutilon are easily distinguished by spines with basal cushions (Figs. 7-8, 1-8). All investigated species related to genus Abutilon characterized by isopolar, prolate spheroidal, trizonoporate pollen grains. The size of pollen grains among the examined species of the genus Abutilon varied between $60.96 \mu \mathrm{m}$ (mean polar axis) in Abutilon pannosum to $79.38 \mu \mathrm{m}$ (mean polar axis) in Abutilon figarianum (Table 2). The average height of spine could be used as a distinguish characters among the investigated taxa of genus Abutilon. However, the shortest spine $(\sim 3.19 \mu \mathrm{m})$ found in Abutilon pannosum, while the longest spine $(\sim 7.08 \mu \mathrm{m})$ found in Abutilon figarianum (Table 2; Fig.12)

Sida is characterized by large pollen grain size. It is of a high taxonomic value among studied species of genus Sida. S. ovata has the largest pollen grain size among all investigated Malvaceous taxa in this study $(138.95 \mu \mathrm{m})$, while it is (94.39 $\mu \mathrm{m}$ ) in S. alba. (Table 2; Fig. 6, 12-20). Moreover, taxa of genus Sida characterized by variable and relatively long spines ( $12.95 \mu \mathrm{m}$ and $\sim 20.65 \mu \mathrm{m}$ in S. alba and S. ovata respectively) (Table 2; Fig. 12). Therefore, the average height of spine is of a high taxonomic value, and easily could be used as discriminative aid among studied species of genus Sida.

Tribe Abutileae includes the subtribes Abutilinae and Sidinae. The pollen grains of the species of this tribe are readily distinguished by spines with basal cushions (Hutchinson, 1967). The large size and long spines of genus Sida is evidence that the species of Sidinae are more advanced than those of Abutilinae (Christensen, 1986).

Hibiscus is easily distinguished by relatively large sized pollen grains ranging from $(\sim 72.86) \mu \mathrm{m}$ in $H$. purpureus to $(\sim 129.17)$ $\mu \mathrm{m}$ in $H$. micranthus (Table 2; Fig. 4, 12, 11), respectively. Moreover, the pollen grains are prolate spheroidal in shape, polypantoporate and apolar (Table 2; Fig. 4, 10-12; Fig. 9, 10-12). The average height of spine among the Hibiscus species is of high taxonomically significant. However, Hibiscus purpureus is easily distinguished by relatively short spines ( $4.43 \mu \mathrm{m}$ ) (Fig. 9, 12) among the closely related species ( $H$. deflersii and $H$. micranthus), which they characterized by relatively long spines ( 12.56 $\mathrm{mm}$ and $\sim 16.85 \mu \mathrm{m}$ ) (Fig. 9, 10-11), respectively.

In the genus Pavonia, the pollen grains are relatively large in size, ranging from $(\sim 87.8 \mu \mathrm{m})$ in $P$. arabica to $(91.5 \mu \mathrm{m})$ in $P$. burchellii (Table 2; Fig. 5, 16; Fig. 6, 17), respectively. The pollen grain size is of a less taxonomic value in distinguishing between investigated taxa of genus Pavonia. The shape of pollen grains is of a high taxonomic value among studied taxa of genus Pavonia. However, it is oblate spheroidal in $P$. arabica and prolate spheroidal in P. burchellii. (Figur 1; Fig. 5 , 16; Fig. 6, 17), respectively. Taxa of genus Pavonia characterized by relatively long spines $(\sim 17.00 \mu \mathrm{m})$. It can be used to distinguish the genus from other Malvaceous taxa. Moreover, spine index also could be served as a discriminative tool among studied Pavonia species (Fig. 13). However, it is (3.81) in $P$. burchellii, while (5.17) in $P$. arabica (Table 2). The pollen morphological character of the studied taxa of Pavonia (tribe Ureneae) presented great similarity in its characters with those of the taxa of Hibisceae. Christensen (1986) concluded that the resemblance in pollen 
Table 1. List of taxa used in the study (Chaudary 1999), a comparison of t traditional (Hutchinson 1967) and phylogenetic classifications (APG IV, 2016).

\begin{tabular}{|c|c|c|c|c|}
\hline No & Taxa & Source and voucher & Hutchinson 1967 & APG IV, 2016 \\
\hline 1 & Abutilon bidentatum Hochst. & Wadii Thalolah near AL-Baha, Suad Al-Ruzayza, 11 (UQU proposed abbreviation) & $\begin{array}{l}\text { Tribe: Abutileae Hutch. } \\
\text { Subtribe: Abutilinae }\end{array}$ & Tribe :Malveae \\
\hline 2 & Abutilon hirtum (Lam.) Sweet, Hort. & Mahil Aseir, Suad Al-Ruzayza, 815 (UQU proposed abbreviation) & $\begin{array}{l}\text { Tribe: Abutileae Hutch. } \\
\text { Subtribe: Abutilinae }\end{array}$ & Tribe :Malveae \\
\hline 3 & Abutilon figarianum Webb, Fragm. & Wadii Qusai, Suad Al-Ruzayza, 5 (UQU proposed abbreviation) & $\begin{array}{l}\text { Tribe: Abutileae Hutch. } \\
\text { Subtribe: Abutilinae }\end{array}$ & Tribe :Malveae \\
\hline 4 & Abutilon fruticosum Guill. \& Perr. & Near Al-Howtah, Alfarhan and J. Thomas, 22274 (KSU) & $\begin{array}{l}\text { Tribe: Abutileae Hutch. } \\
\text { Subtribe: Abutilinae }\end{array}$ & Tribe :Malveae \\
\hline 5 & Abutilon pannosum (G.Forst.) Schltdl. & Al-Edabi, Suad Al-Ruzayza, 17 (UQU proposed abbreviation) & $\begin{array}{l}\text { Tribe: Abutileae Hutch. } \\
\text { Subtribe: Abutilinae }\end{array}$ & Tribe :Malveae \\
\hline 6 & Abutilon ramosum (Cav.) Guill. \& Perr. & Shada mountiain, Suad Al-Ruzayza,2 (UQU proposed abbreviation) & $\begin{array}{l}\text { Tribe: Abutileae Hutch. } \\
\text { Subtribe: Abutilinae }\end{array}$ & Tribe :Malveae \\
\hline 7 & Abutilon grandifolium (Willd.) Sweet & Fifa mountain, Suad Al-Ruzayza,15 (UQU proposed abbreviation) & $\begin{array}{l}\text { Tribe: Abutileae Hutch. } \\
\text { Subtribe: Abutilinae }\end{array}$ & Tribe :Malveae \\
\hline 8 & Abutilon muticum Sweet, Hort. & Alardah, Suad Al-Ruzayza,6 (UQU proposed abbreviation) & $\begin{array}{l}\text { Tribe: Abutileae Hutch. } \\
\text { Subtribe: Abutilinae }\end{array}$ & Tribe :Malveae \\
\hline 9 & Althaea ludwigii L. & Qassim Road, Suad Al-Ruzayza, 22 (UQU proposed abbreviation) & Tribe: Malveae A. Gray & Tribe :Malveae \\
\hline 10 & Hibiscus deflersii Schweinf. ex Cufod. & Taif, Suad Al-Ruzayza , 37 (UQU proposed abbreviation) & Tribe: Hibisceae Endl & Tribe: Hibiscieae \\
\hline 11 & Hibiscus purpureus L. & Fifa mountain, Alfarhan and J. Thomas, 999 (KSU) & Tribe: Hibisceae Endl & Tribe: Hibiscieae \\
\hline 12 & Hibiscus micranthus L.f. & Raidah, Suad Al-Ruzayza, 34 (UQU proposed abbreviation) & Tribe: Hibisceae Endl & Tribe: Hibiscieae \\
\hline 13 & Sida alba L., & Fifa mountain, J. Thomas and R. basahi, 21876 (KSU) & Tribe: Abutileae Hutch. Subtribe: Sidinae (K.Schum.) Hutch & Tribe :Malveae \\
\hline 14 & Sida ovata Forssk. & Fifa mountain,Mohamed Ibrahim 2033 (KSU) & Tribe: Abutileae Hutch. Subtribe: Sidinae (K.Schum.) Hutch & Tribe :Malveae \\
\hline 15 & Malva parviflora L., & Alkarj, Suad Al-Ruzayza, 29 (UQU proposed abbreviation) & $\begin{array}{l}\text { Tribe: Malveae A. Gray } \\
\text { Subtribe : Malvinae }\end{array}$ & Tribe :Malveae \\
\hline 16 & Malva verticillata $\mathrm{L}$., & AL-ahsaa, Suad Al-Ruzayza, 32 (UQU proposed abbreviation) & Tribe: Malveae A. Gray Subtribe : Malvinae & Tribe :Malveae \\
\hline 17 & Malva neglecta Wallr. & Ushaqur, near Riyadh, Suad Al-Ruzayza, 2 (UQU proposed abbreviation) & $\begin{array}{l}\text { Tribe: Malveae A. Gray } \\
\text { Subtribe: Malvinae }\end{array}$ & Tribe :Malveae \\
\hline 18 & Pavonia arabica Hochst. \& Steud. ex Boiss., & Wadi Bani Zaher, S. Chaudhary, 7087 (RAWRC) & Tribe: Ureneae Benth. \& Hook & Tribe: Hibiscieae \\
\hline 19 & Pavonia burchellii (DC.) R.A. Dyer & Jeddah, Suad Al-Ruzayza, 40 (UQU proposed abbreviation) & Tribe: Ureneae Benth. \& Hook & Tribe: Hibiscieae \\
\hline 20 & Senra incana Cav., & Harrat Al-Shara, Suad Al-Ruzayza, 41(UQU proposed abbreviation) & Tribe: Hibiscieae & Tribe: Hibiscieae \\
\hline
\end{tabular}


Table 2. Pollen morphological characters of the investigated taxa of Malvaceae in Saudi Arabia.

\begin{tabular}{|c|c|c|c|c|c|c|c|c|c|c|c|}
\hline No. & Taxon & Polar axis $(P) \mu \mathrm{m}$ & $\begin{array}{l}\text { Equatorial axis (E) } \\
\text { um }\end{array}$ & $P / E$ & Pollen shape & Aperature character & Polarity & Exine sculpture & $\begin{array}{l}\text { Average height of } \\
\text { spine } \mu \mathrm{m}\end{array}$ & $\begin{array}{l}\text { Average width of } \\
\text { spine } \mu \mathrm{m}\end{array}$ & Spine index \\
\hline 1 & Abutilon grandifolium & 76.78 & 73.97 & 1.04 & Prolate spheroidal & Trizonoporate & Isopolar & Echinate & 4.68 & 1.82 & 2.57 \\
\hline 2 & Abutilon hirtum & 75.06 & 71.98 & 1.05 & Prolate spheroidal & Trizonoporate & Isopolar & Echinate & 6.02 & 1.69 & 3.56 \\
\hline 3 & Abutilon bidentatum & 75.67 & 73.19 & 1.04 & Prolate spheroidal & Trizonoporate & Isopolar & Echinate & 5.17 & 1.09 & 4.74 \\
\hline 4 & Abutilon muticum & 68.37 & 63.56 & 1.08 & Prolate spheroidal & Trizonoporate & Isopolar & Echinate & 7.32 & 2.29 & 3.20 \\
\hline 5 & Abutilon pannosum & 60.96 & 59.23 & 1.03 & Prolate spheroidal & Trizonoporate & Isopolar & Echinate & 3.19 & 1.08 & 2.95 \\
\hline 6 & Abutilon figarianum & 79.38 & 77.2 & 1.03 & Prolate spheroidal & Trizonoporate & Isopolar & Echinate & 7.08 & 1.57 & 4.51 \\
\hline 7 & Abutilon fruticosum & 75.02 & 72.74 & 1.04 & Prolate spheroidal & Trizonoporate & Isopolar & Echinate & 5.22 & 1.30 & 4.02 \\
\hline 8 & Abutilon ramosum & 62.66 & 61.34 & 1.03 & Prolate spheroidal & Trizonoporate & Isopolar & Echinate & 4.08 & 1.09 & 3.74 \\
\hline 9 & Althaea ludwigii & 101.62 & 97.12 & 1.05 & Prolate spheroidal & Polypantoporate & Apolar & Echinate & 5.99 & 1.92 & 3.12 \\
\hline 10 & Hibiscus deflersii & 96.3 & 91.26 & 1.06 & Prolate spheroidal & Polypantoporate & Apolar & Echinate & 12.56 & 4.19 & 3.00 \\
\hline 11 & Hibiscus micranthus & 129.17 & 117.78 & 1.10 & Prolate spheroidal & Polypantoporate & Apolar & Echinate & 16.85 & 4.98 & 3.38 \\
\hline 12 & Hibiscus purpureus & 72.86 & 71.68 & 1.02 & Prolate spheroidal & Polypantoporate & Apolar & Echinate & 4.43 & 1.37 & 3.23 \\
\hline 13 & Malva neglecta & 56.06 & 57.56 & 0.98 & Oblate spheroidal & Polypantoporate & Apolar & Echinate & 6.03 & 1.88 & 3.21 \\
\hline 14 & Malva parviflora & 52.28 & 60.11 & 0.87 & Suboblate & Polypantoporate & Apolar & Echinate & 4.80 & 2.30 & 2.09 \\
\hline 15 & Malva verticillata & 82.2 & 84.36 & 0.98 & Oblate spheroidal & Polypantoporate & Apolar & Echinate & 6.78 & 1.67 & 4.06 \\
\hline 16 & Pavonia arabica & 87.8 & 90.57 & 0.97 & Oblate spheroidal & Polypantoporate & Apolar & Echinate & 16.85 & 3.26 & 5.17 \\
\hline 17 & Pavonia burchellii & 91.5 & 88.27 & 1.04 & Prolate spheroidal & Polypantoporate & Apolar & Echinate & 16.06 & 4.22 & 3.81 \\
\hline 18 & Senra incana & 69.52 & 69.32 & 1.00 & Spheroidal & Polypantoporate & Apolar & Echinate & 3.86 & 1.74 & 2.22 \\
\hline 19 & Sida alba & 94.39 & 99.31 & 0.96 & Oblate spheroidal & Polypantoporate & Apolar & Echinate & 12.95 & 3.80 & 3.41 \\
\hline 20 & Sida ovata & 138.95 & 139.96 & 0.99 & Oblate spheroidal & Polypantoporate & Apolar & Echinate & 20.65 & 4.73 & 4.37 \\
\hline
\end{tabular}

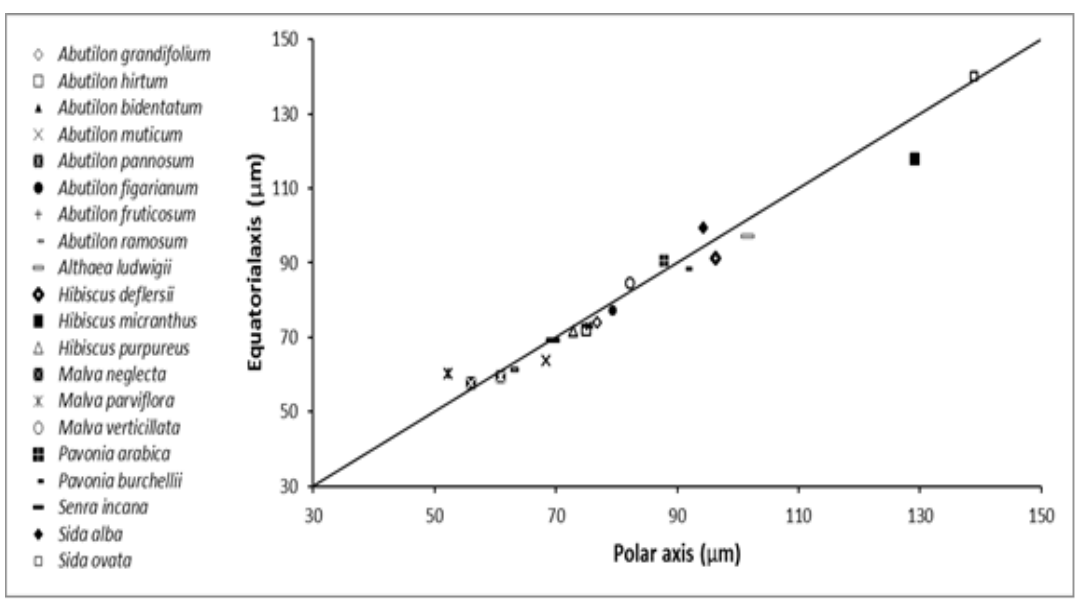

Fig 1. Pollen size and shape. 


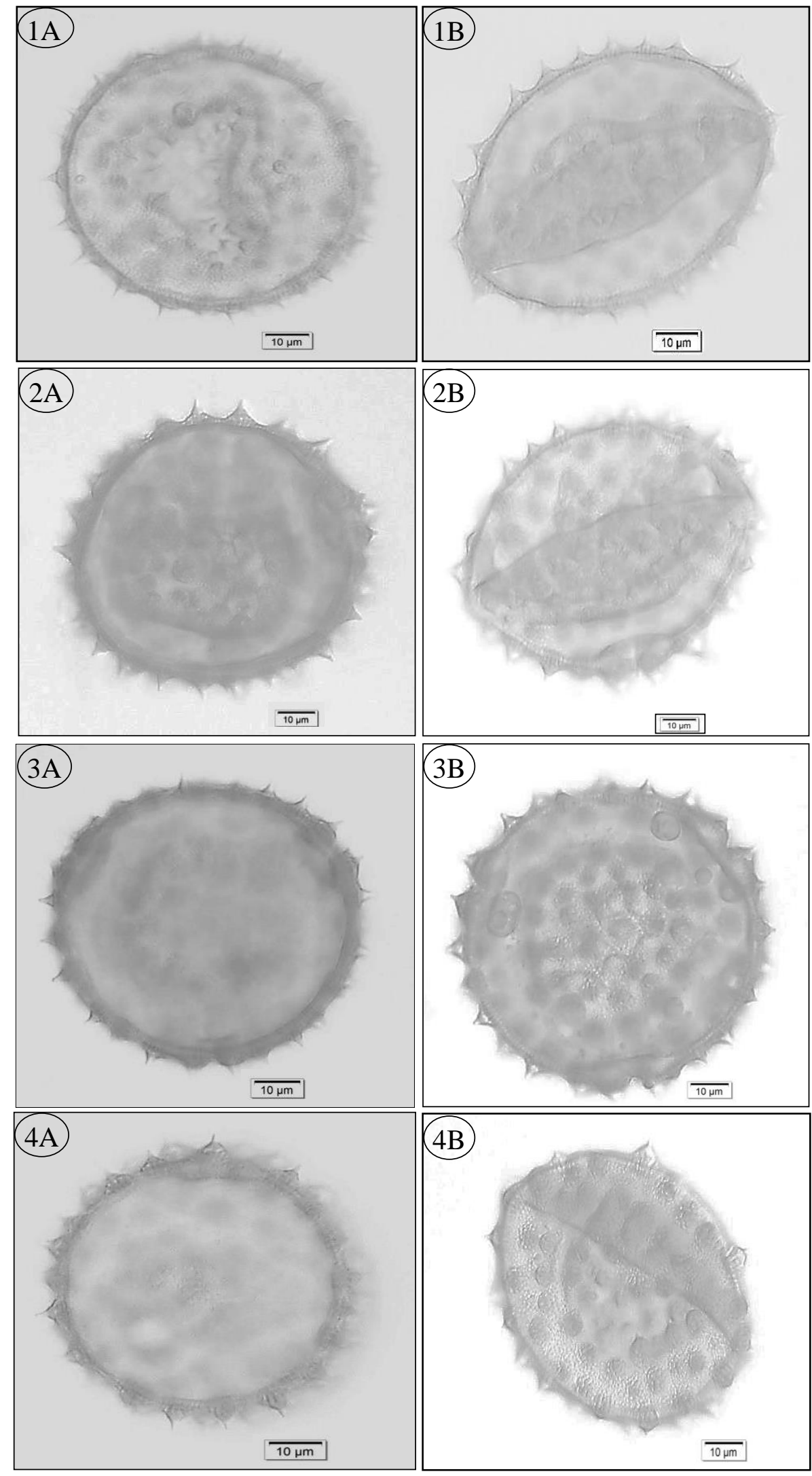

Fig 2. LM micrographs of pollen grains. (A) Polar view, (B) equatorial view. 1. Abutilon bidentatum; 2. Abutilon grandifolium; 3. Abutilon hirtum; 4. Abutilon muticum. 

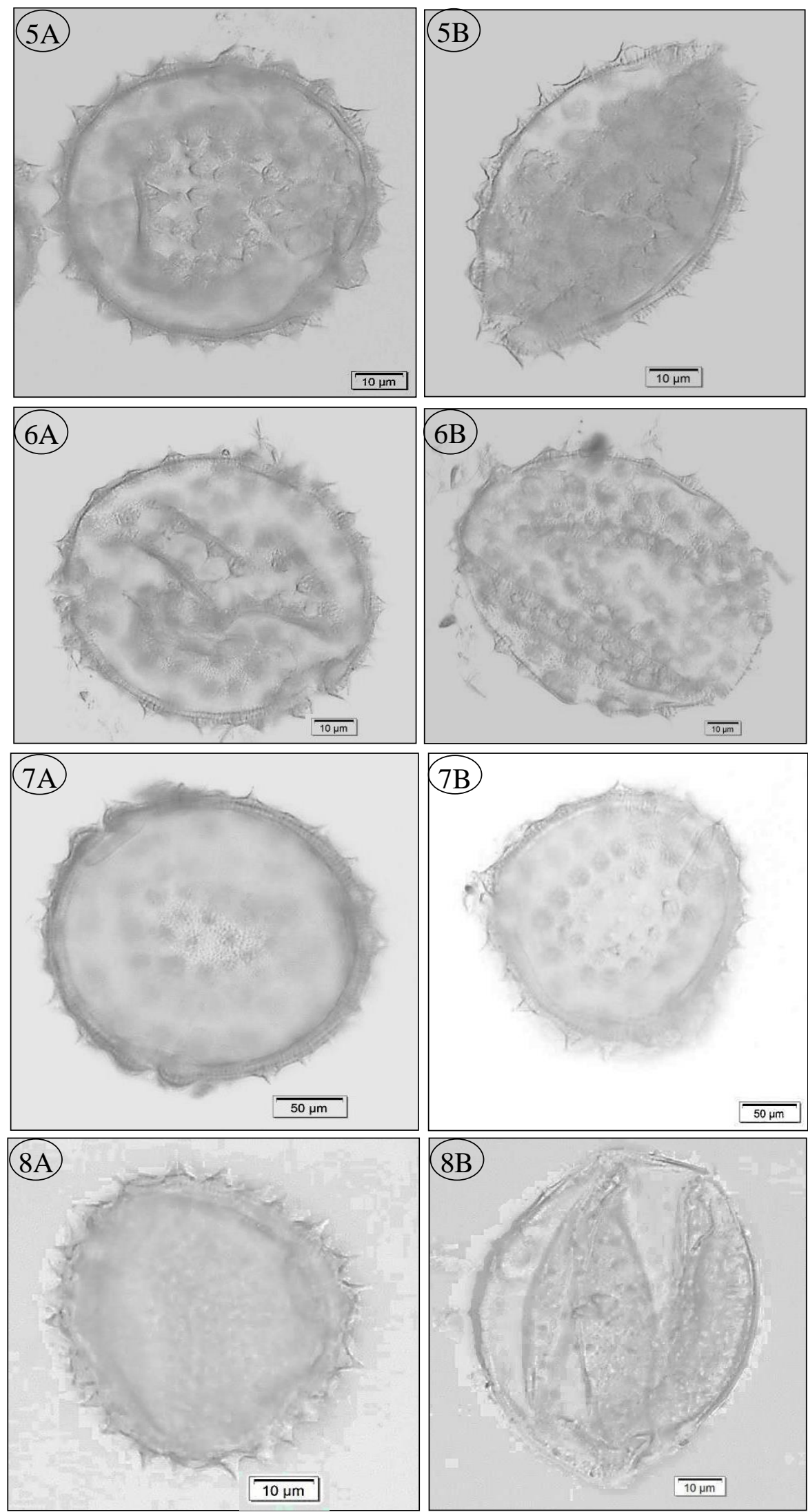

Fig 3. LM micrographs of pollen grains. (A) Polar view, (B) equatorial view. 5. Abutilon pannosum; 6. Abutilon figarianum; 7. Abutilon fruticosum; 8. Abutilon ramosum. 


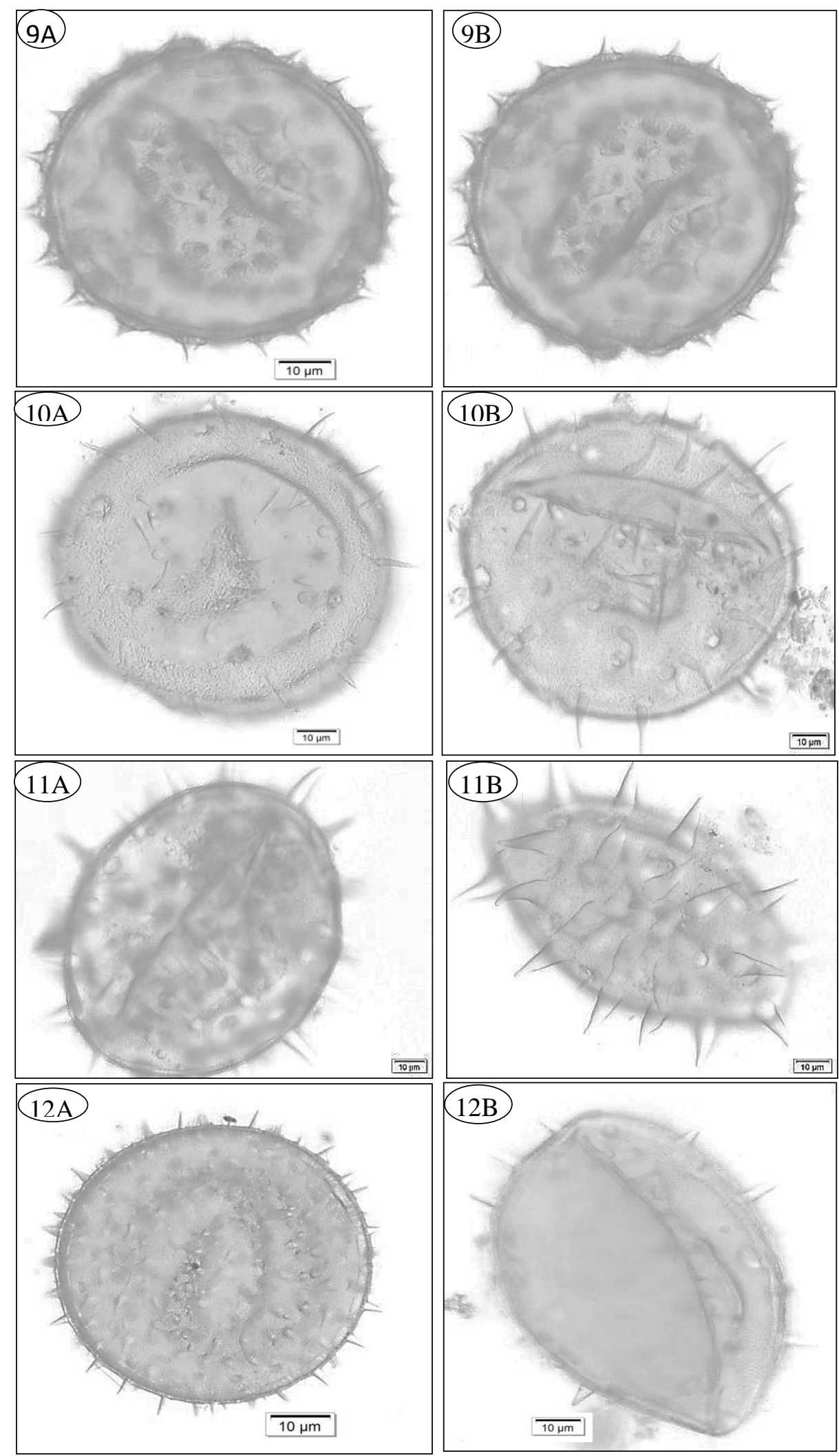

Fig 4. LM micrographs of pollen grains. (A) Polar view, (B) equatorial view. 9. Althaea ludwigii; 10. Hibiscus deflersii; 11. Hibiscus micranthus; 12 . Hibiscus purpureus. 


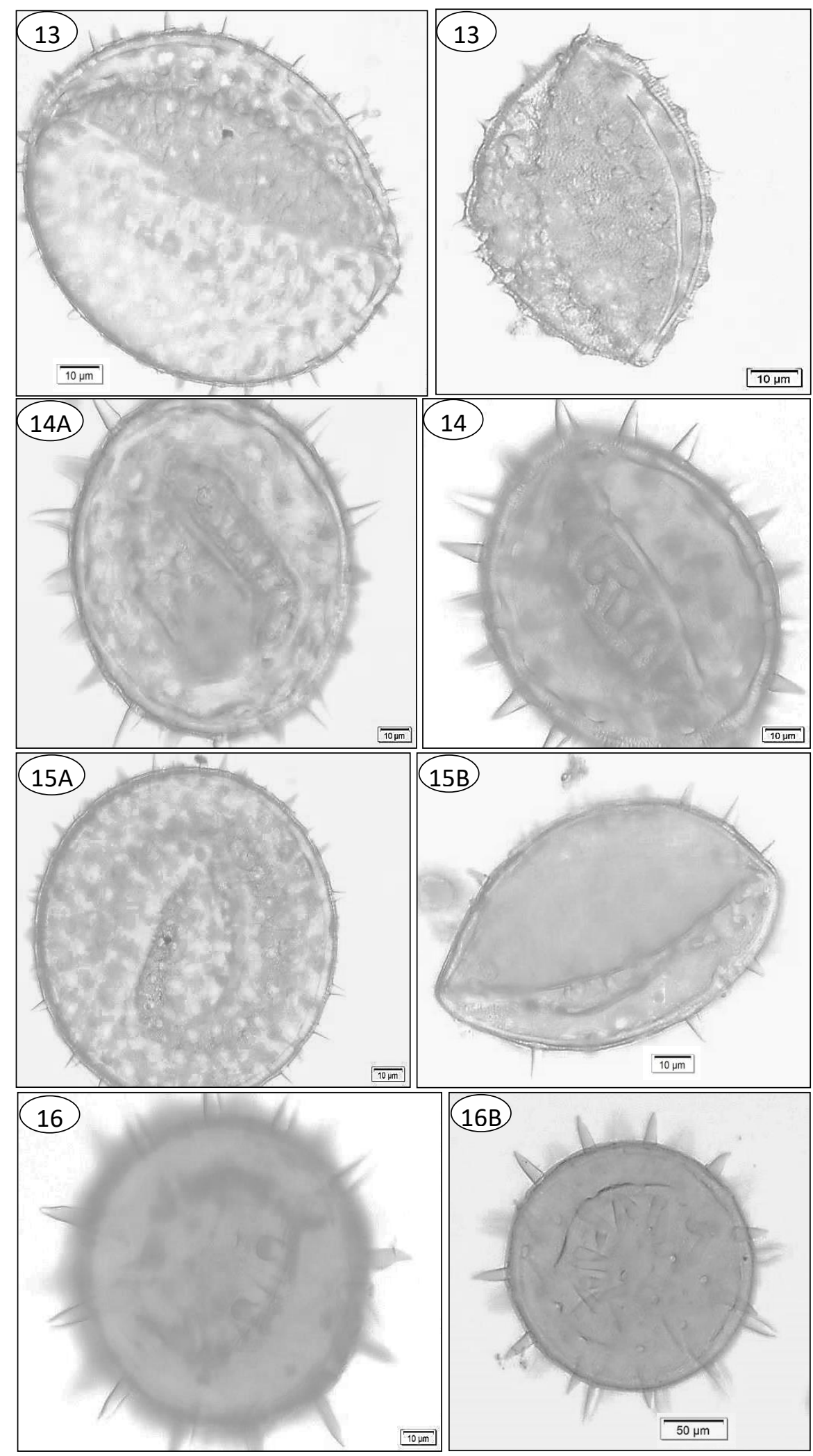

Fig 5. LM micrographs of pollen grains. (A) Polar view, (B) equatorial view. 13. Malva neglecta; 14. Malva parviflora; 15. Malva verticillata; 16. Pavonia arabica. 


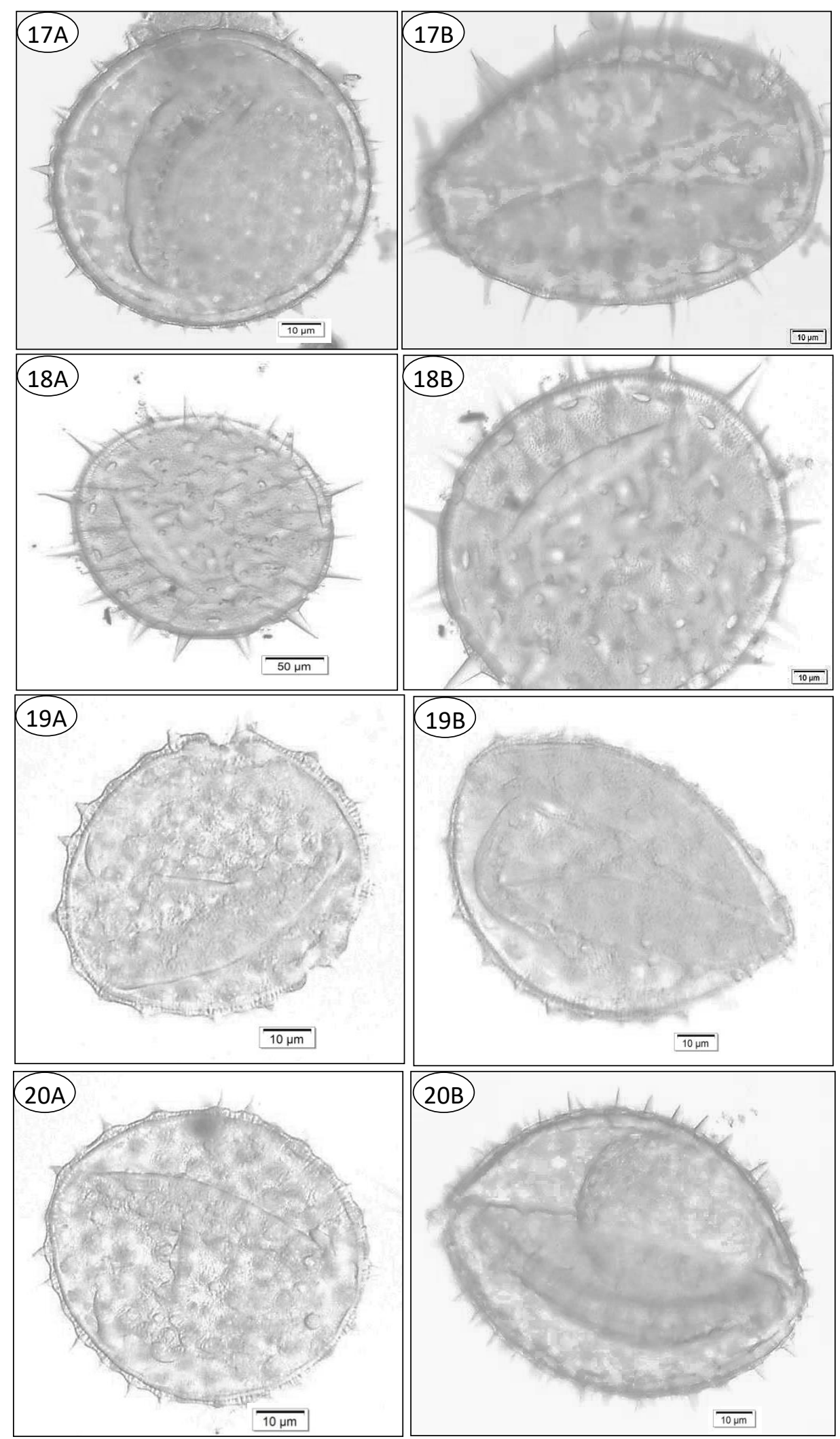

Fig 6. LM micrographs of pollen grains. (A) Polar view, (B) equatorial view. 17. Pavonia burchellii; 18. Senra incana; 19. Sida alba; 20. Sida ovata. 

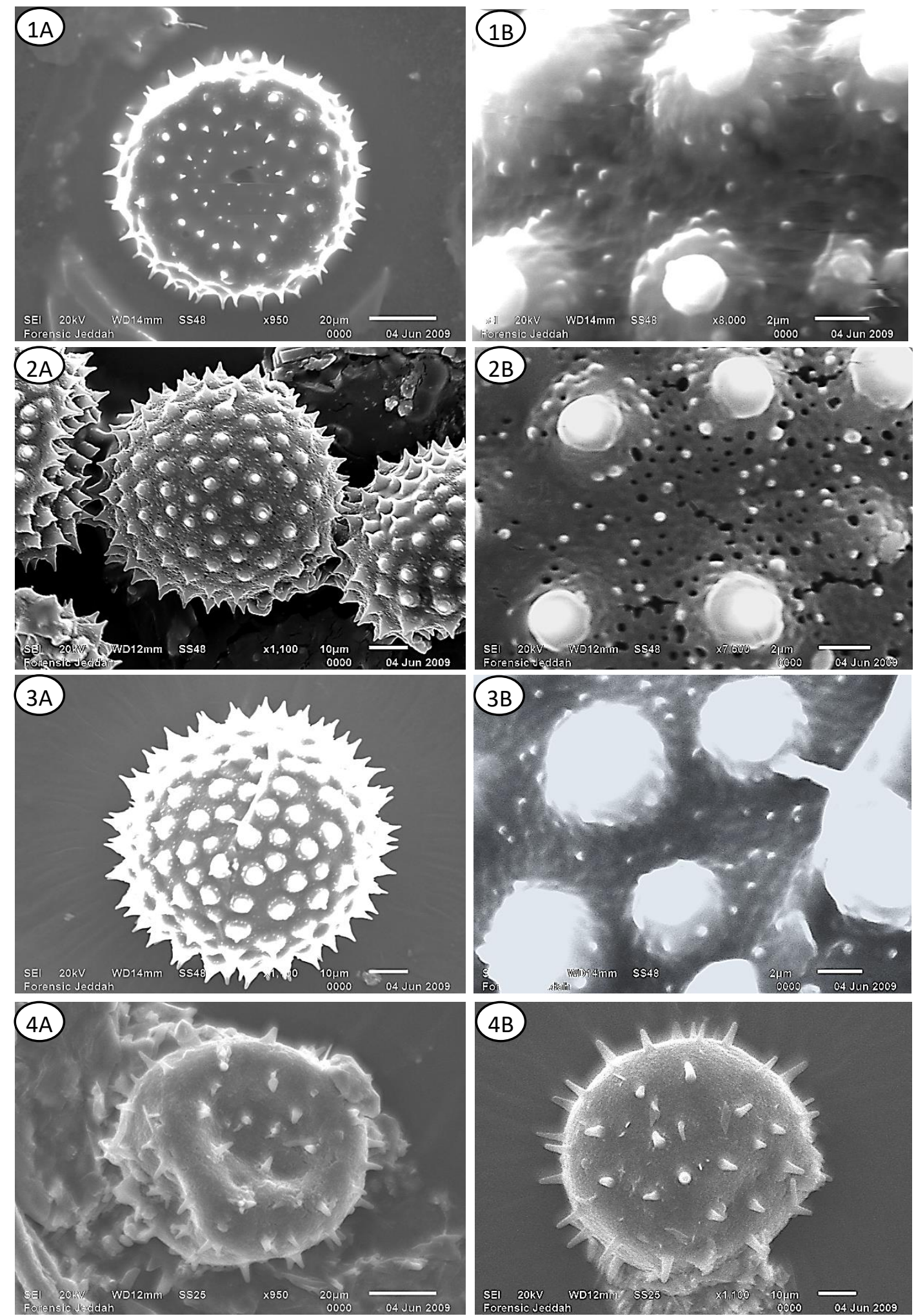

Fig 7. SEM micrographs of pollen grains. (A) entire pollen grains, (B) surface ornamentation of exine. 1. Abutilon bidentatum; 2. Abutilon grandifolium; 3. Abutilon hirtum; 4. Abutilon muticum. 

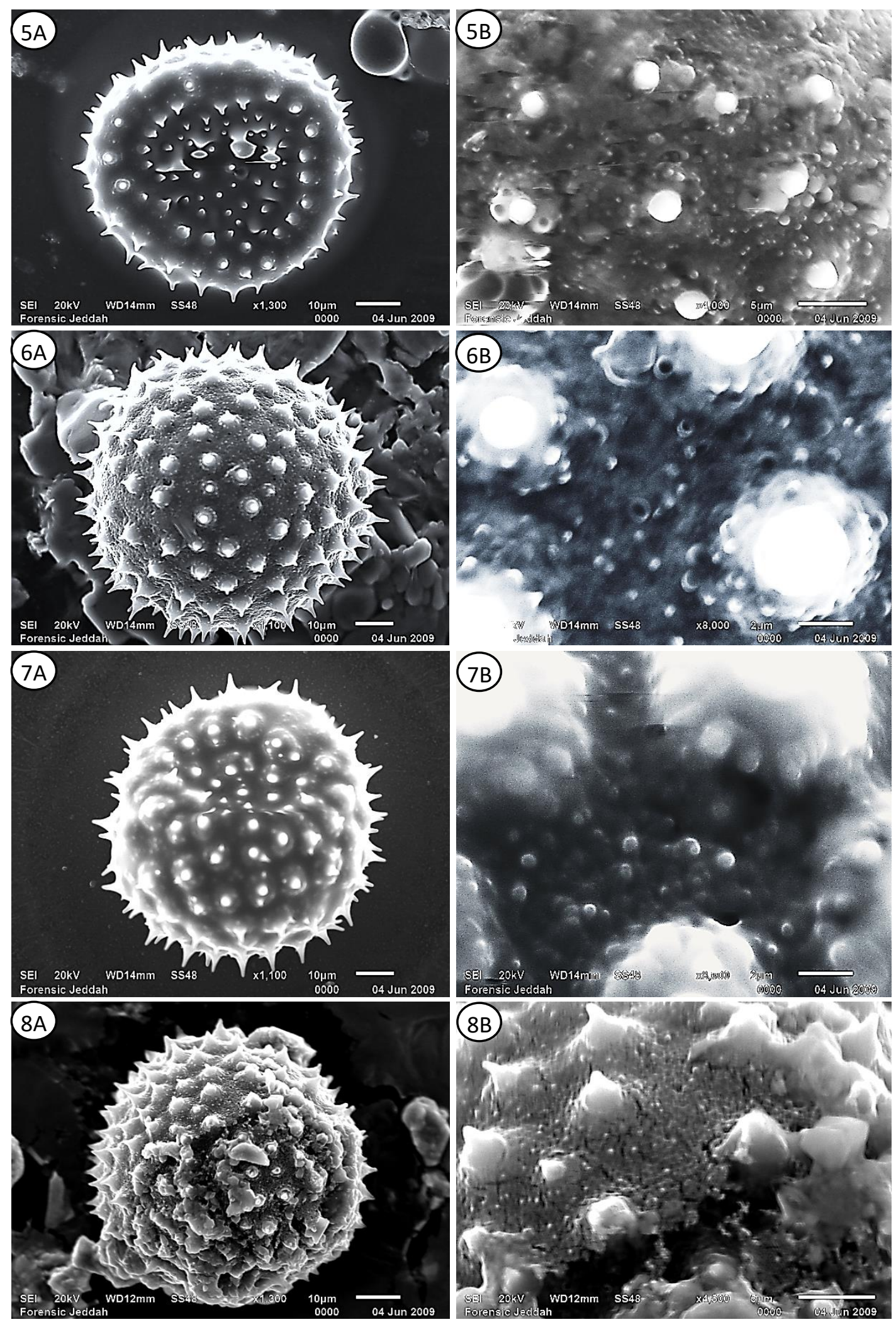

Fig 8. SEM micrographs of pollen grains. (A) entire pollen grains, (B) surface ornamentation of exine. 5. Abutilon pannosum; 6. Abutilon figarianum; 7. Abutilon fruticosum; 8. Abutilon ramosum. 

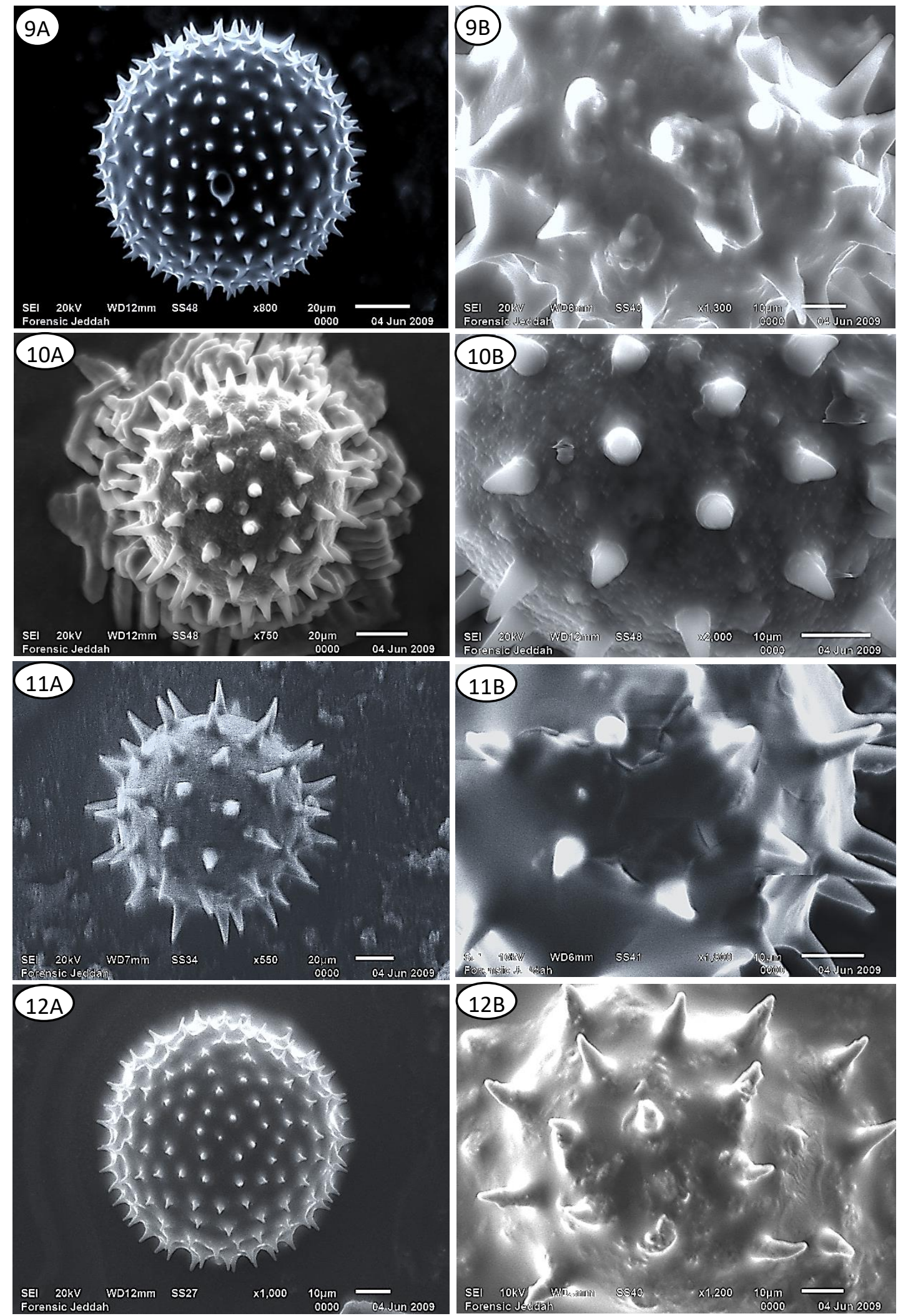

Fig 9. SEM micrographs of pollen grains. (A) entire pollen grains, (B) surface ornamentation of exine. 9. Althaea ludwigii; 10. Hibiscus deflersii; 11. Hibiscus micranthus; 12. Hibiscus purpureus. 


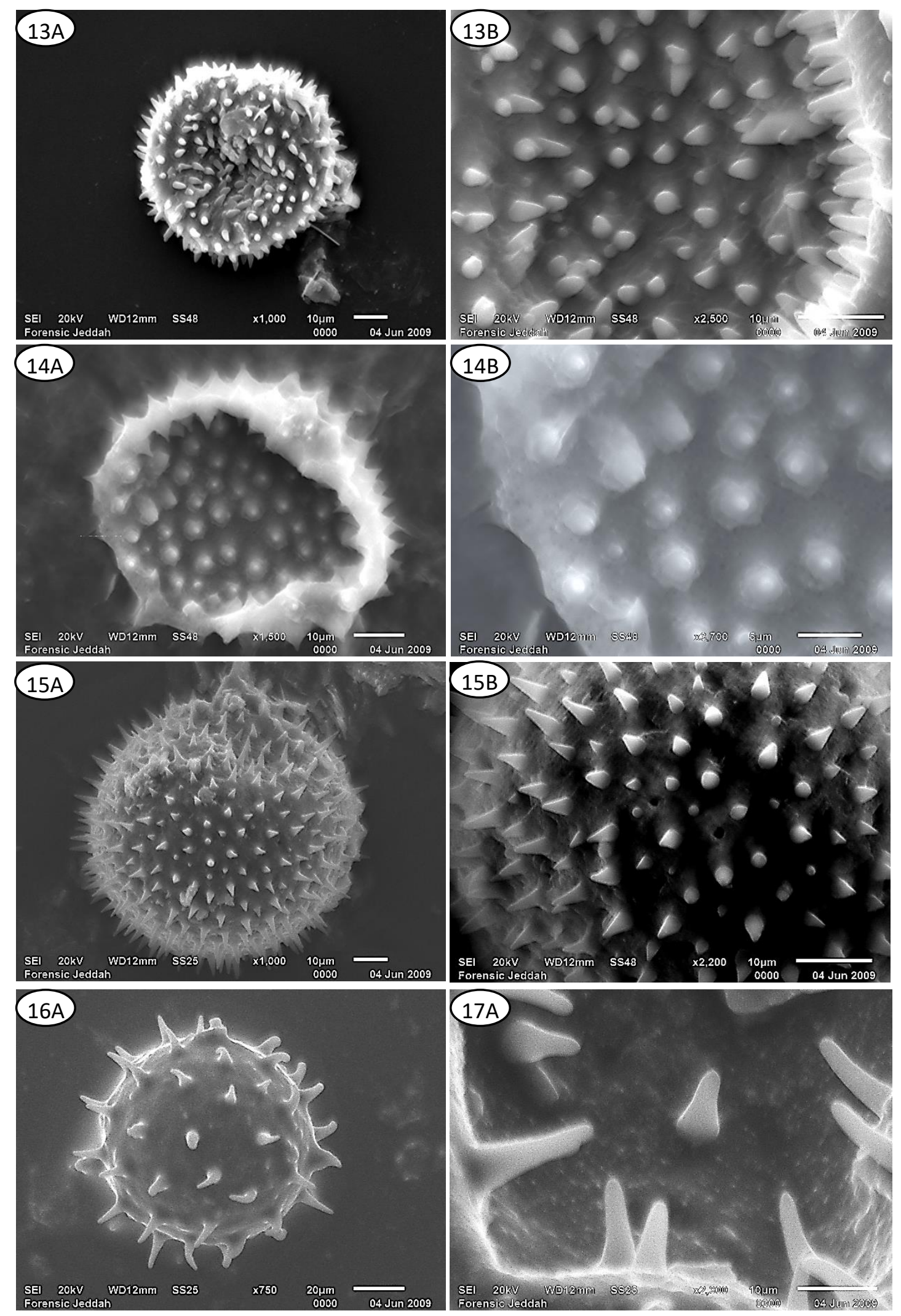

Fig 10. SEM micrographs of pollen grains. (A) entire pollen grains, (B) surface ornamentation of exine. 13. Malva neglecta; 14. Malva parviflora; 15. Malva verticillata; 16. Pavonia arabica. 


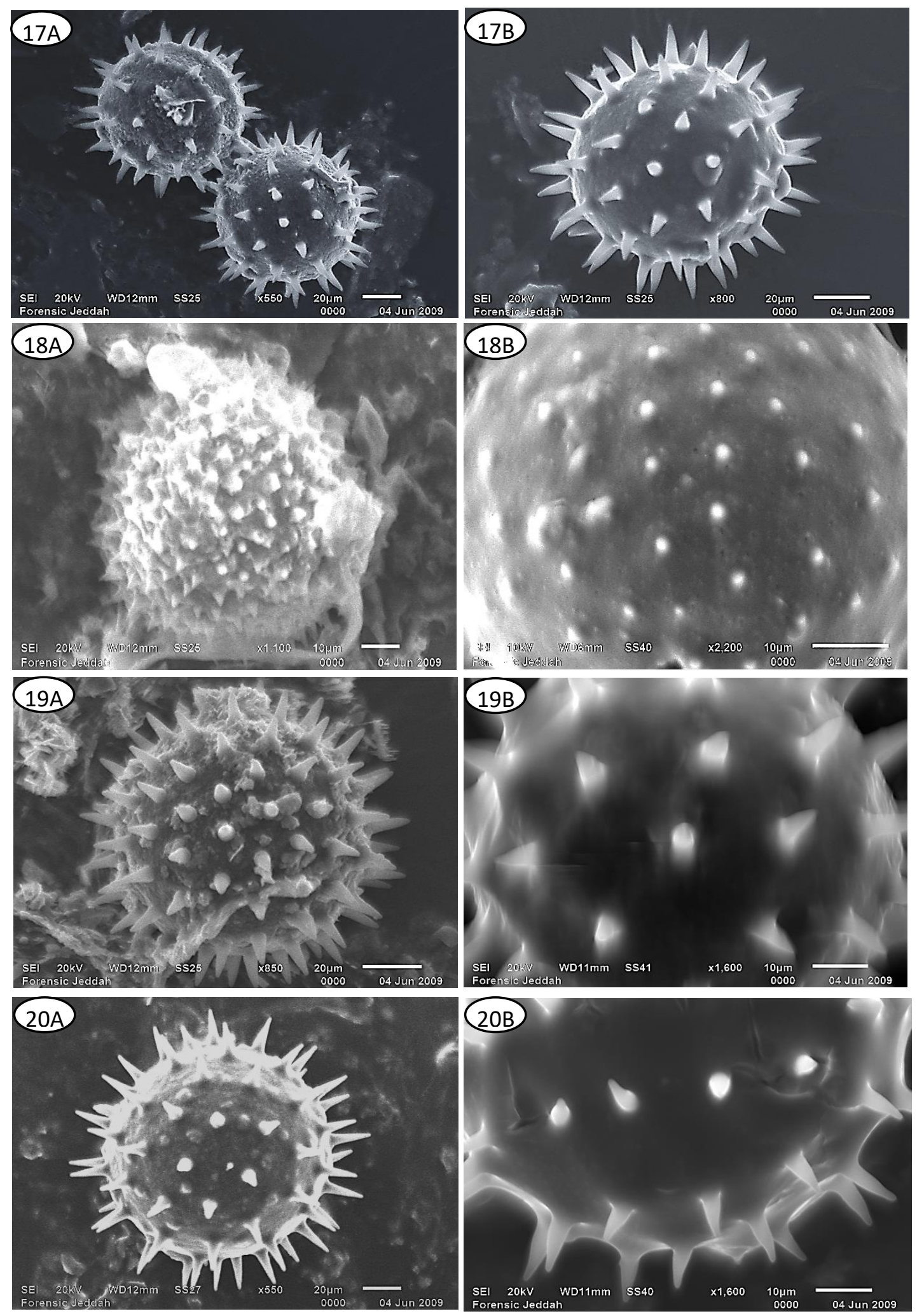

Fig 11. SEM micrographs of pollen grains. (A) entire pollen grains, (B) surface ornamentation of exine. 17. Pavonia burchellii; 18. Senra incana; 19. Sida alba; 20. Sida ovata. 


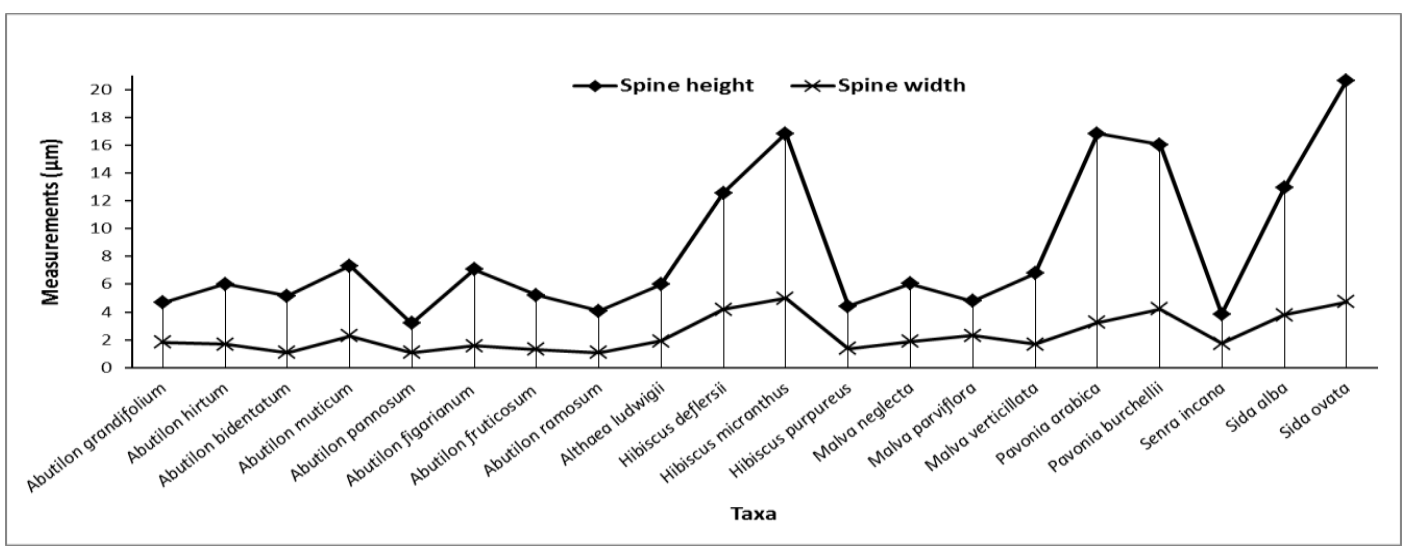

Fig. 12. Spine height and width variation among the investigated Malvaceous taxa.

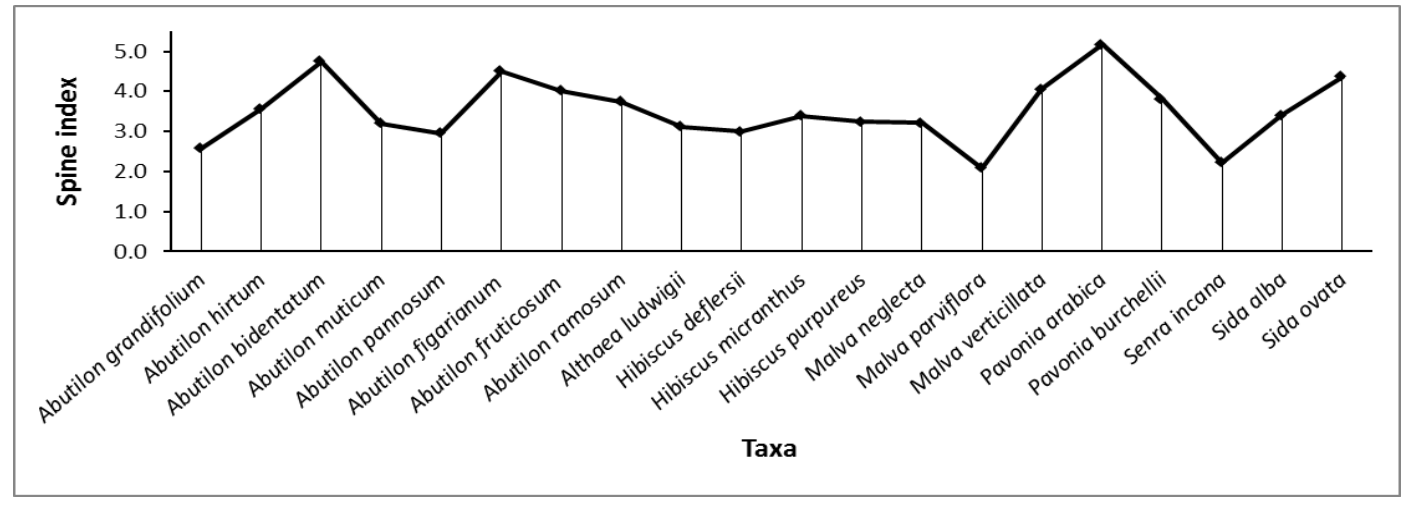

Fig 13. Variation in spine index of investigated Malvaceous taxa.

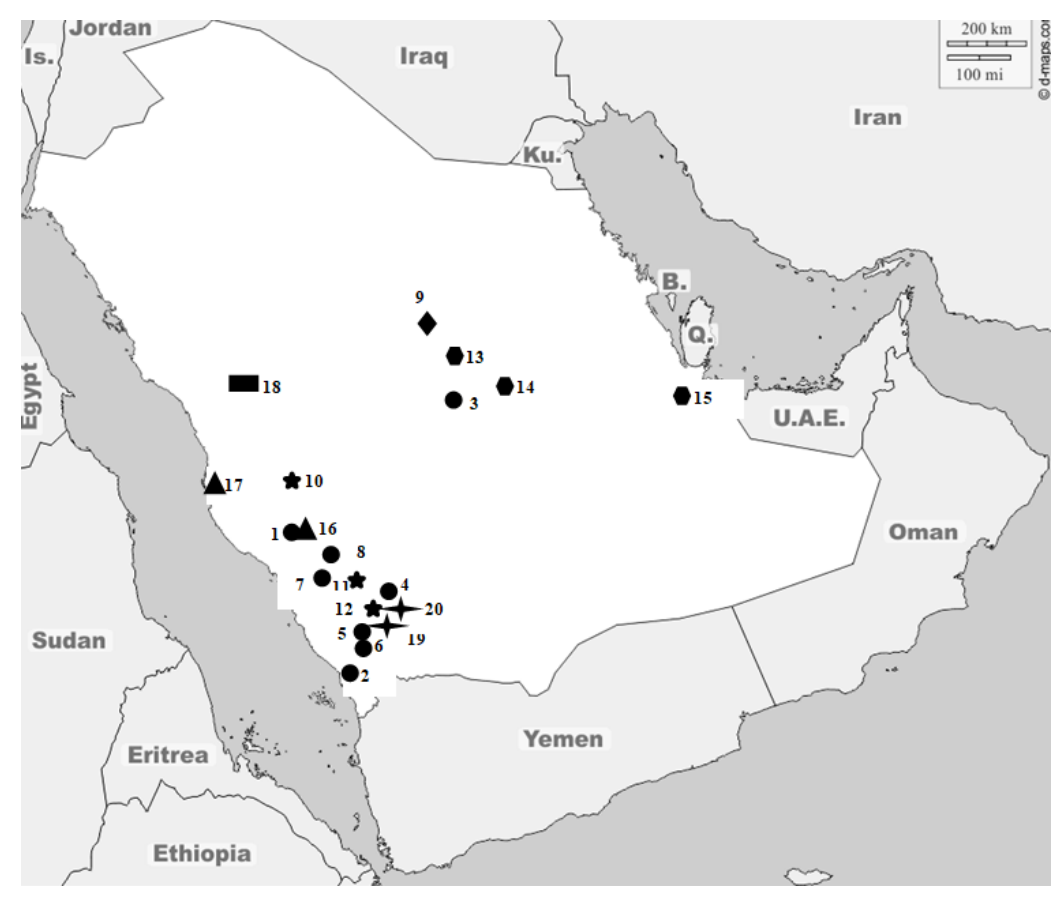

Fig 14. Location map of Malvaceae in Saudi Arabia. O1. Abutilon bidentatum. 2. Abutilon figarianum. 3. Abutilon fruticosum. 4. Abutilon grandifolium. 5. Abutilon hirtum. 6. Abutilon muticum.7. Abutilon pannosum. 8. Abutilon ramosum 9. Althaea Ludwigii. $\star$ Ł10. Hibiscus deflersii. 11. Hibiscus micranthus. 12. Hibiscus purpureus. $\boldsymbol{\Delta}$ 13. Malva neglecta. 14. Malva parviflora.15. Malva verticillata 16. Pavonia arabica. 17. Pavonia burchelii. 18. Senra incana. + 19. Sida alba.20. Sida ovata. 
features of both tribes could be explained by parallel evolution.

The pollen grains of genus Malva characterized by relatively medium size ranging from $(\sim 52.28 \mu \mathrm{m})$ in Malva parviflora to $(\sim 82.2 \mu \mathrm{m})$ in Malva verticillata (Table 2; Fig. 5, 13-15). Pollen grain shape was found to be useful in discriminate Malva parviflora from the other closely related studied species. However, Malva parviflora has suboblate shape, while Malva neglecta and Malva verticillata have oblate spheroidal (Table 2 and Fig. 1).

Althaea ludwigii characterized by relatively large pollen grain size $(\sim 101.62 \mu \mathrm{m})$, Prolate spheroidal in shape, polypantoporate, average height of spine is about $(6.00 \mu \mathrm{m})$ and $3.12 \mu \mathrm{m}$ spine index (Table 2; Fig 4, 9; Fig. 9, 9).

The pollen grains of Senra incana characterized by relatively small size among investigated taxa $(\sim 69.52 \mu \mathrm{m})$; Spheroidal in shape, Polypantoporate, average height of spine is about $(3.86 \mu \mathrm{m})$ and 2.22 spine index (Table 2; Fig. 6, 18; Fig. 11, 18).

The current findings agree with those of Perveen et al., (1994), El Naggar (2004), and Hosni and Araffa (1999) that pollen grain in Malvaceae are usually spheroidal or globular in outline and are colporate or porate with an echinate sculpture. Tectum uniformly echinate with monomorphic spine in most of the taxa.

\section{Materials and Methods}

The present study is based on the pollen morphology of 20 wild taxa belonging to seven genera of family Malvaceae. Samples of pollen of each species were collected from living material or herbarium specimens (Table 1, Fig. 14).

For light microscopy (LM) pollen grains were acetolysed according to Erdtman (1952) and Reitsma (1969). Before acetolysis the pollens were treated with $10 \% \mathrm{KOH}$ for about 10 minutes to remove the oils and waxes to open the apertures and making them easier to study. Pollen grains were then mounted in safranin-stained glycerin jelly and micro morphological observations were made with Olympus type BH-2. Photomicrographs were taken with Olympus photomicroscope

For Scanning Electron Microscopy (SEM) acetolysed pollen grains were directly transferred to aluminum stub covered with double sided cello tape and the stubs were sputtercoated with gold for $5 \mathrm{~min}$ in an E1100 (Polaron Equipment). After coating, the specimens were examined with a Jeol JSM 5200 scanning electron microscope and using accelerating voltages at $20-25 \mathrm{KV}$. All photomicrographs were taken at the central laboratory of Forensic Criminal evidence-Ministry of Interior, Jeddah, Saudi Arabia. The measurements were based on 15-20 readings from each specimen. Various pollen characters viz. pollen class, shape, size, aperture, and exine ornamentation were investigated and the terminology used is in accordance with (Erdtman, 1952; Kremp, 1965; Huang, 1972; Faegri and Iverson, 1975).

\section{Conclusion}

The pollen morphology of the investigated taxa of the Malvaceae suggests that some characters are of a high taxonomic value and can be useful in evaluating the taxonomic relationships among the studied species. These include pollen polarity, symmetry, size, shape, polar axis, equatorial diameter, $P / E$ ratio, average height and width of spine, aperature character and spine index. Palynological markers can be used as a reliable tool to delimit Abutilon, Hibiscus and Sida at generic level. It is further concluded that data from palynological studies is of significant taxonomic importance and must be integrated with traditional morphology-based classification to delimit different taxa at the specific level.

\section{Acknowledgement}

The authors would like to thank the Research and Development Grants Program for National Research Institutes and Centers (GRANTS), Graduate Research Program, King Abdulaziz City for Science and Technology (KACST), Kingdom of Saudi Arabia, grant number (Project ID: 1-18-01-007-0001) for the financial funding. Also, we are thankful to the herbarium director and curator of the King Saud University and Agriculture and Water Research Center, Riyadh (KSU and RAWRC).

\section{References}

APG IV (2016) An update of the Angiosperm Phylogeny Group classification for the orders and families of flowering plants. Bot J Linn Soc. 181(1): 1-20.

Barth OM (1975) Catálogo sistemático dos pólens das plantas arbóreas do Brasil Meridional: XVIII-Malvaceae. Mem Inst Oswaldo Cruz. 73(1-2):1-18.

Chaudhary S (1999) Flora of Kingdom Of Saudi Arabia. Riyadh: Ministry of Agriculture and Water.

Chaudhuri SK (1965) Pollen morphological studies of the order Malvales II. BullBot Soc Bengal. 19:147-158.

Christenhusz MJM, Byng JW (2016) The number of known plants species in the world and its annual increase. Phytotaxa. 261(3):201-217.

Christensen PB (1986) Pollen morphological studies in the Malvaceae. Grana. 25(2):95-117.

Coetzee J, Van Der Schijff HP (1979) Pollen morphology of south african malvales. i: characteristics useful for keying and for numerical analysis.

Culhane KJ, Blackmore S (1988) Malvaceae. Rev Palaeobot Palyno. 57(1-2): 45-74.

El Naggar SM (2001) Systematic implications of seed coat morphology in Malvaceae. Pak JBiol Sci. 4: 822-828.

El Naggar SM (2004) Pollen morphology of Egyptian Malvaceae: an assessment of taxonomic value. Turk J Bot. 28(1-2):227-240.

El-Hadidi MN, Araffa S (1999) Malvaceae in the flora of Egypt 1. Systematic revision of the indigenous taxa. Taeckholmia.19(2):147-156.

Erdtman G (1952) Pollen morphology and plant taxonomy Angiosperms Almqvist \& Wiksell. Slockholm.

Erdtman G (1969) Handbook of palynolgy: Morphology, taxonomy, ecology. An introduction to the study of pollen grains and spores. Hafner.

Faegri K, Iverson J (1975) Textbook of Pollen Analysis. 3rd ed. Edited by K. Faegri. Munksgaard, Copenhagen.: Hafner Press, New York. 295pp.

Fernandez I, Candau P (1981) Palinologia de Malvaceae en Andalucia. Bot Macaron. 8(9):119-128.

Hanks S, Fryxell PA (1979) Palynological studies of Gaya and Herissantia (Malvaceae). Am J Bot. 66(5):494-501. 
Hosni H, Araffa S (1999) Malvaceae in the flora of Egypt 2. Pollen morphology and its taxonomic significance. Taeckholmia.19(2):147-156.

Huang TC (1972) Pollen flora of Taiwan. National Taiwan University Botany Department Press, pp. 297; PI: 177.

Hutchinson J (1967) The Genera of Flowering Plants (Angiospermae) Dicotyledones. Vol. 2'. Clarendon Press, Oxford.

Krapovickas A (1975) Acaulimalva, nuevo genero de Malvaceas. Darwiniania 19:9-39.

Krebs G (1994a) Taxonomische Untersuchungen in der Subtribus Malvinae. Feddes Repert 105(1-2):7-18.

Krebs G (1994b) 'Taxonomische Untersuchungen in der Subtribus Malvinae II. Dinacrusa. Feddes Repert 105(5-6): 299-315.

Kremp GOW (1965) Morphologic Encyclopedia of Palynology: An Internat. Coll. of Definitions and III. of Spores and Pollen. University of Arizona Press.

La Duke JC, Doebley J (1995) A Chloroplast DNA Based Phylogeny of the Malvaceae. Syst Bot 20: 259-271.

Martin PS, Drew CM (1969) Scanning electron photomicrographs of southwestern pollen grains. J Ariz Acad Sci. 5(3):147-176.

Nair PK (1958) Dimorphic spines in the pollen of Malva parviflora. J Sci Indust. 17: 35-36.

Nair PK (1961) Pollen grains of cultivated plants. II. Bougainvillaea Comm., Hibiscus Medik, and Euphorbia pulcherrima Willd. J Indian Bot Soc. 40:365-381.

Perveen A (1993) A preliminary study of the pollen flora of Karachi. University of Karachi.
Perveen A, Qaiser A (1994) Pollen flora of Pakistan-I, Malvaceae. Pak J Bot. 26(2): 421-440.

Pope MA (1925) Pollen morphology as an index to plant relationship. I. Morphology of pollen. Bot Gaz 80(1):63-73.

Prasad SS (1963) Pollen grain morphology of certain Malvaceae. J Ind Bot Soc. 42: 463-468.

Punt W, Hoen P, Blackmore S, Nilsson S, Thomas A (1994) Glossary of pollen and spore terminology: LPP Contributions series No. 1', Netherlands: Laboratory of Palaeobotany and Palynology, University of Utrecht.

Reitsma T (1969) Size modifications of recent pollen grains under different treatments. Rev Palaeobot Palynol. 69: 23-47.

Saad SI (1960) The sporoderm stratification in the Malvaceae. Pollen Spores. 2:13-41.

Srivastava D (1982) Studies in the pollen biology of certain cultivated malvaceae, in Advances in pollen spore research (ed. P. K. K. Nair). Today and Tomorrow's Printers \& Publishers, p. 165

Stevens PF (2001) Angiosperm Phylogeny Website, Version 14.

Tahavi M (2000) Palynological studies of arboreal plants growing in lahore and their impact on aeropalynology. University of Punjab.

Tressens SG (1974) Los granos de polen de los géneros Malvastrum y Acaulimalva (Malvaceae). Darwiniana. 19: 40-64.

Van Campo M (1976) Pollen et phylogenie Les breviaxes. Pollen Spores. 8: 57-73. 